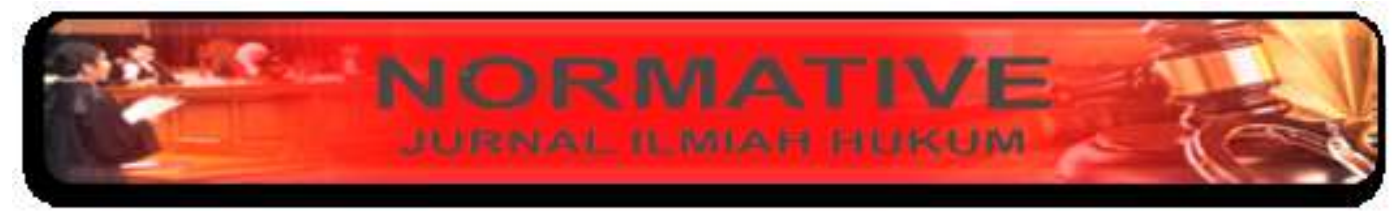

Jurnal Normative Volume 5 Nomor 2 Tahun 2017 ISSN : 1907-5820

\title{
TINJAUAN HUKUM ISLAM TERHADAP ZAKAT FITRAH DALAM BENTUK UANG
}

\author{
Joni Zulhendra, Fakultas Hukum Universitas Tamansiswa Padang \\ jonizulhendra@yahoo.co.id
}

\begin{abstract}
Zakat is one form of worship to Allah, it has a very big social aspect. Shari'ah has completely established its provisions; of what property should be zoned up to the target of distribution. With zakat the needs of the ummah can be fulfilled, including poverty eradication. Zakat fitrah is a maliyah ritual performed every year. Zakat fitrah payments generally use rice as a staple food that is commonly consumed by the community. But there are also paying or organizing the management of zakat fitrah with money. If using rice, zakat fitrah is paid $2.5 \mathrm{~kg}$ of rice. If using the money, zakat fitrah paid to adjust the price of rice in the market. It is therefore easier for people to earn money than basic food items. Thus, giving zakat in the form of money proved to have provided benefit for the people and this is permissible under Islamic law.
\end{abstract}

Keyword : Zakat fitrah, The form of money, Islamic Law.

\section{A. Pendahuluan}

Zakat merupakan suatu ibadah yang dipergunakan untuk kemaslahatan umat sehingga dengan adanya zakat (baik zakat fitrah maupun zakat maal) kita dapat mempererat tali silaturahmi dengan sesama umat Islam maupun dengan umat lain. Zakat suatu kewajiban bagi umat Islam yang digunakan untuk membantu masyarakat lain, menstabilkan ekonomi masyarakat dari kalangan bawah hingga kalangan atas, sehingga dengan adanya zakat umat Islam tidak ada yang tertindas karena zakat dapat menghilangkan jarak antara si kaya dan si miskin. Oleh karena itu, zakat sebagai salah satu instrumen negara dan juga sebuah tawaran solusi untuk menbangkitkan bangsa dari keterpurukan. Zakat juga sebuah ibadah mahdhah yang diwajibkan bagi orang-orang Islam, namun diperuntukan bagi kepentingan seluruh masyarakat.

Oleh karena itu kesadaran untuk menunaikan zakat bagi umat Islam harus ditingkatkan baik dalam menunaikan zakat fitrah yang hanya setahun sekali pada bulan ramadhan, maupun zakat maal yang seharusnya dilakukan sesuai dengan ketentuan zakat dalam yang telah ditetapkan baik harta, hewan ternak, emas, perak dan sebagainya. Sebagaimana yang kita ketahui pada setiap Hari Raya Idul Fitri, setiap orang Islam baik laki-laki maupun perempuan, besar kecil, merdeka atau hamba, diwajibkan membayar zakat fitrah dari makanan yang mengenyangkan menurut tiap-tiap tempat (negeri). 


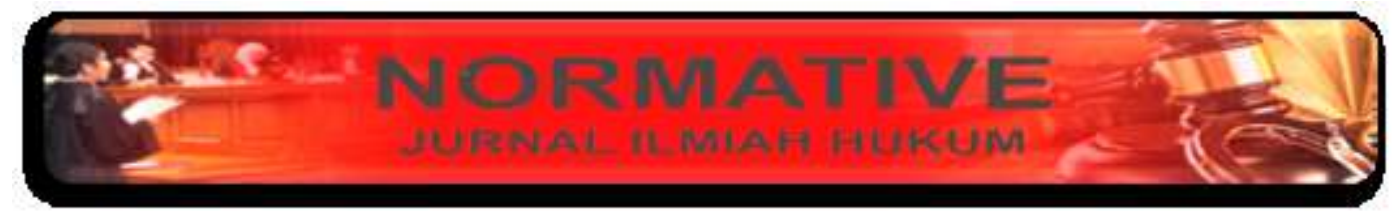

Jurnal Normative Volume 5 Nomor 2 Tahun 2017 ISSN : 1907-5820

Zakat dalam syariat islam menunjukkan bahwa Islam sangat memperhatikan masalahmasalah kemasyarakatan terutama nasib mereka yang lemah. Sehingga memperdekat hubungan kasih sayang antara sesama manusia dalam mewujudkan persaudaraan Islam. Sejalan dengan pandangan Islam di atas, maka zakat merupakan salah satu syarat mutlak di dalam membina masyarakat muslim. Salah satu tujuan zakat yang terenting adalah mempersempit ketimpangan ekonomi di dalam masyarakat hingga batas yang seminimal mungkin tujuannya adalah menjadikan perbedaan ekonomi masyarakat secara adil dan seksama, sehingga yang kaya dan yang miskin tidak saling mengeksploitasi sehingga yang miskin semakin miskin. Hal ini pada beberapa kesematan Rasulullah Saw menyebutkan bahwa mereka yang berhak menerima zakat hanyalah orangorang miskin karena tujuannya adalah menghapus kemiskinan.

Persyariatan zakat di dalam Islam menunjukkan bahwa Islam sangat memperhatikan masalah-masalah kemasyarakatan terutama nasib mereka yang lemah. Sehingga memperdekat hubungan kasih sayang antara sesama manusia dalam mewujudkan persaudaraan Islam.

Adanya kesadaran seseorang dalam melaksanakan syariat Allah SWT merupakan suatu bukti ketebalan iman serta keyakinan hamba terhadap sang pencipta, apalagi dalam masalah zakat. karena nilai pengabdiannya bukan hanya ditujukan pada pencipta alam semesta saja, tapi juga merupakan bentuk kontribusi yang sangat besar terhadap kaum fakir miskin, sehingga mereka bisa merasakan dan menikmati hak-hak mereka secara layak. Pentingnya perkara zakat ini memberi dampak terhadap tegaknya agama Islam karena ini merupakan suatu pondasi serta rukun Islam yang harus dipegang oleh pemeluknya. Memang tidak bisa diragukan lagi keberadaannya bahwa zakat itu suatu rukun Islam dan wajib dilaksanakan oleh manusia.

Di era globalisasi ini banyak orang yang tidak mengerti bagaimana cara yang benar untuk mendayagunakan zakat fitrah. Maka wajib bagi kita untuk membenarkan masalahmasalah yang timbul dalam masyarakat. Untuk itu perlu adanya kerangka pemikiran yang dapat menjelaskan keluasan arti benda yang digunakan untuk zakat fitrah dalam rangka pembangunan nasional ke dalam pos-pos penggunaan yang memang masih dalam pengertian teks al-Qur'an tentang yang berhak menerima zakat, sebagaimana dalam alQur'an surat At-Taubah ayat 60. 


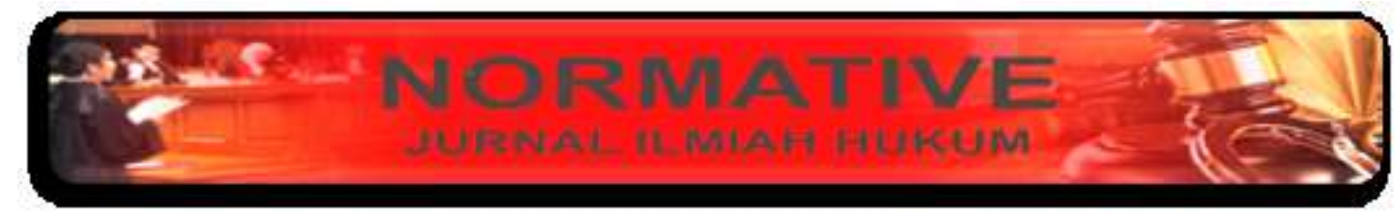

Jurnal Normative Volume 5 Nomor 2 Tahun 2017 ISSN : 1907-5820

Arti dari surat At-Taubah ayat 60, yaitu sesungguhnya zakat-zakat itu, hanyalah untuk orang-orang fakir, orang-orang miskin, pengurus-pengurus zakat, Para mu'allaf yang dibujuk hatinya, untuk (memerdekakan) budak, orang-orang yang berhutang, untuk jalan Allah SWT dan untuk mereka yuang sedang dalam perjalanan, sebagai suatu ketetapan yang diwajibkan Allah SWT, dan Allah SWT Maha mengetahui lagi Maha Bijaksana. (QS. At-Taubah : 60).

Dari ayat di atas dijelaskan bahwa, sesungguhnya zakat-zakat itu hanyalah untuk orang-orang fakir, orang-orang miskin, pengurus-pengurus zakat, para muallaf yang dibujuk hatinya, untuk (memerdekakan) budak, orang-orang yang berutang, untuk jalan Allah SWT, dan orang-orang yang sedang dalam perjalanan.

Melihat dari penjelasan di atas terkait kewajiban dan pengelolaan serta pendistribusian zakat fitrah yang sesuai dengan hukum Islam, maka perlu bagi kita untuk mengetahui apa yang seharusnya dilaksanakan di masyarakat dan bagaimanakah konsep zakat fitrah yang dihanti dengan uang. Berkaitan dengan itu, penulis tertarik membuat karya ilmiah dengan judul "Tinjauan Hukum Islam Terhadap Zakat Fitrah Dalam Bentuk Uang".

\section{B. Rumusan Masalah}

Dalam tulisan ini dirumuskan tentang zakat fitrah dalam bentuk uang ditinjau menurut hukum Islam.

\section{Pembahasan Tentang Zakat}

a. Tinjauan Umum Tentang Zakat Fitrah

Zakat fitrah dinamakan al-fitri yang mengacu kepada kata fitri yang artinya adalah makan. Dinamakan zakat fitri karena terkait dengan bentuk harta yang diberikan kepada mustahiknya, yaitu berupa makanan. Selain itu zakat ini dinamakan fitri juga karena terkait dengan hari lebaran yang bernama fitri. Kita di Indonesia sering menyebutnya dengan hari Raya Fitri. dan di hari Idul Fitri itu kita diharamkan berpuasa, sebaliknya wajib berbuka atau memakan makanan. Oleh karena itulah hari raya itu disebut dengan hari Idul Fitri dan arti secara bahasanya adalah hari raya makan-makan.

Zakat fitrah dapat diartikan dengan suci sebagaimana hadits Rasul "kullu mauludin yuladu ala al fitrah" (setiap anak Adam terlahir dalam keadaan suci) dan bisa juga diartikan juga dengan ciptaan atau asal kejadian manusia. Zakat 


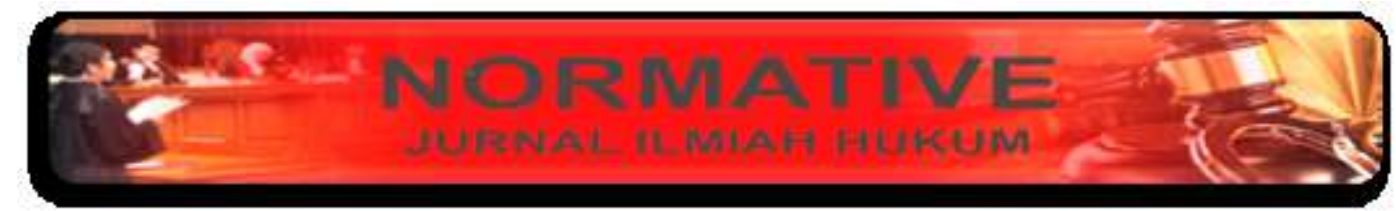

Jurnal Normative Volume 5 Nomor 2 Tahun 2017 ISSN : 1907-5820

fitrah ini dimaksudkan untuk membersihkan dosa-dosa yang pernah dilakukan selama puasa Ramadhan, agar orang-orang itu benarbenar kembali kepada keadaan fitrah, dan juga untuk menggembirakan hati fakir miskin pada hari raya idul fitri.

Dari pengertian di atas dapat ditarik dua pengertian tentang zakat fitrah. Pertama, zakat fitrah adalah zakat untuk kesucian. Artinya, zakat ini dikeluarkan untuk mensucikan orang yang berpuasa dari ucapan atau perilaku yang tidak ada manfaatnya. Kedua, zakat fitrah adalah zakat karena sebab ciptaan. Artinya bahwa zakat fitrah adalah zakat yang diwajibkan kepada setiap orang yang dilahirkan ke dunia ini. Oleh karenanya zakat ini bisa juga disebut dengan zakat badan atau pribadi.

b. Syarat-syarat Wajib Zakat Fitrah

Syarat-syarat wajib zakat fitrah adalah sebagai berikut : a. Islam. Orang yang tidak beragama Islam tidak wajib membayar zakat fitrah. b. Lahir sebelum terbenam matahari (menjumpai waktu tenggelamnya matahari) pada hari penghabisan bulan Ramadan. c. Mempunyai lebihan harta dari keperluan makanan untuk dirinya sendiri dan untuk yang wajib dinafkahinya, baik manusia ataupun binatang, pada malam hari raya dan siang harinya. Orang yang tidak mempunyai lebihan tidak wajib membayar fitrah.

Zakat fitrah ini hukumnya wajib atas setiap manusia yang muslim, baik dia sudah dewasa maupun ketika masih kanak-kanak. Bahkan janin yang masih ada di dalam perut ibunya dan sudah bernyawa, termasuk yang terkena kewajiban untuk dikeluarkan zakatnya. Zakat ini juga tetap wajib atas laki-laki dan wanita, yang berakal atau pun yang tidak berakal.

Adapun waktu pembayarannya adalah ketika masih dibulan ramadhan karena zakat fitrah adalah ibadah yang tidak bisa dilepaskan dengan rangkaian ibadah di bulan Ramadhan, sebab kewajiban berzakat fitrah hanya boleh dilakukan pada bulan Ramadhan. Dengan kata lain apabila zakat fitrah dilakukan di luar buan Ramadhan, bisa dipastikan bahwa status zakat fitrah yang dibayarkan menjadi tidak sah. Rasulullah dalam salah satu haditsnya yang diriwayatkan oleh Ibnu Abbas menjelaskan, yang artinya : Barangsiapa yang membayar zakat fitrah sebelum dia melaksanaan shalat iedul fitri, maka zakat fitrahnya diterima 


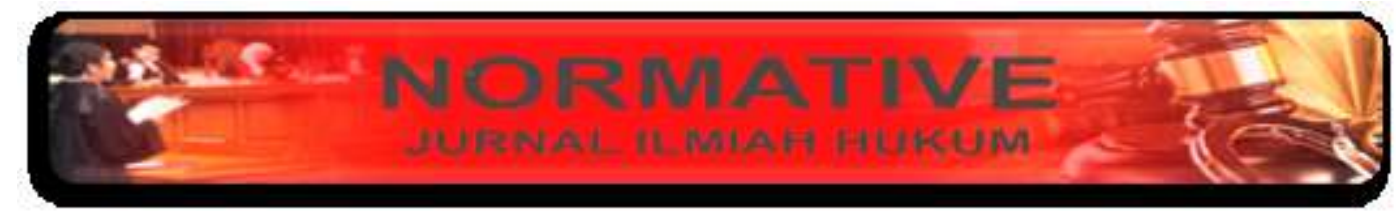

Jurnal Normative Volume 5 Nomor 2 Tahun 2017 ISSN : 1907-5820

(dinyatakan sah), akan tetapi barangsiapa yang mengeluarkannya setelah melaksanakan shalat idul fitri, maka zakat fitrahnya hanya dianggap sebagai sedekah biasa.

\section{c. Jenis Zakat yang Dibayarkan}

Sebagaimana kita ketahui bahwa ada banyak jenis zakat, dan biasanya tiap jenis harta ada zakatnya sendiri-sendiri dan masing-masing punya ketentuan yang juga saling berbeda. Zakat fitrah adalah salah satu dari sekian banyak jenis zakat, oleh karena itu ada bentuk yang wajib dizakatkan, ukuran, dan juga kapan waktu yang ditetapkan untuk membayarkannya.

Para ulama sepakat bahwa bentuk zakat fitrah itu adalah apa yang menjadi makanan pokok, yaitu :

- Makanan Pokok

Bagi masyarakat Madinah di masa Nabi Muhammad Saw, kurma di masa itu menjadi bahan makanan pokok sehari-hari. Ibaratnya makan pagi, siang dan malam mereka adalah kurma. dan Rasulullah Saw ketika menjadi penduduk Madinah, memang ikut juga makan kurma, sebagaimana umumnya penduduk Madinah. Oleh karena itu, beliau Rasulullah Saw membayar zakat fitrah dengan kurma. Selain kurma yang menjadi makanan pokok, pada masa Rasulullah Saw juga mengeluarkan zakat fitrah dengan gandum, karena umumnya masyarakat Arab di masa itu, bahkan hingga hari ini, makanan pokok mereka adalah roti yang terbuat dari gandum.

Bagaimana kalau di negara lain seperti negara Indonesia, yang mana makanan pokoknya bukan kurma atau gandum seperti yang ada pada zaman Nabi Muhammad Saw atau di Saudi Arabiya. Para ulama umumnya sepakat mengatakan bahwa meski zakat itu merupakan makanan, tetapi yang diberikan bukan makanan yang sudah matang dan siap disantap. Tetapi bentuknya adalah bahan mentah yang belum dimasak.

Salah satu alasannya adalah bahwa makanan yang sudah matang dan siap santap tidak bertahan lama dan tidak bisa disimpan. Setidaknya untuk ukuran teknologi di masa lalu yang belum mengenal sistem pengawetan makanan. Sedangkan bila yang diberikan berupa bahan mentah, seperti 


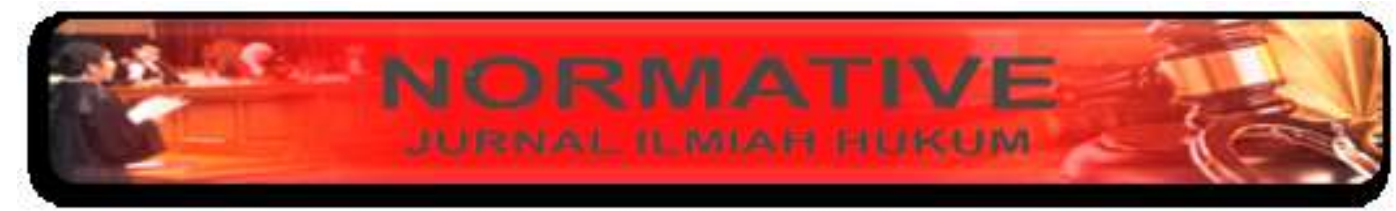

Jurnal Normative Volume 5 Nomor 2 Tahun 2017 ISSN : 1907-5820

beras, gandum dan sejenisnya, maka bahan-bahan itu bisa disimpan oleh orang yang menerima zakat untuk waktu yang lama. Karena itu di Indonesia pada umumnya adalah menggunakan beras, atau jagung di Madura, sagu di Papua dan lain-lain tergantung jenis makanan pokok yang ada di daerah tertentu.

- Ukuran

Sesuai dengan hadits di atas, disebutkan bahwa Nabi Muhammad Saw mengeluarkan gandum atau kurma dengan ukuran satu sha'. Setidaknya para ulama sepakat bahwa Nabi Muhammad Saw mengeluarkan zakat fitrah sebesar satu sha'. Jumhur ulama sepakat bahwa ukuran zakat fitrah yang dikeluarkan oleh Rasulullah Saw adalah satu sha' dengan haditshadits yang pada umumnya tidak lepas dari menyebutkan jumlah satu sha' itu.

Satu hal yang perlu dicatat bahwa ukuran sha' disepakati oleh para ulama merupakan ukuran takaran atau volume, bukan ukuran berat. Hal itu didasarkan pada sabda Rasulullah Saw sendiri dalam salah satu hadits yang diriwayatkan oleh dari Ibnu Umar RA berkata bahwa Rasulullah Saw bersabda yang artinya : Ukuran volume mengikuti ukuran yang dipakai oleh penduduk Madinah, sedangkan ukuran berat mengikut ukuran berat yang dipakai penduduk Mekkah.

\section{d. Orang yang Berhak Menerima Zakat}

Dari penerima zakat yang disebutkan dalam ayat 60 surat at-Taubah, penerima zakat dilihat dari penyebabnya dan dapat dikelompokkan dalam dua kelompok besar, yaitu :

1. Ketidak mampuan dan ketidak berdayaan

Kelompok atau golongan yang masuk dalam kategori ini dapat dibedakan pada dua hal, yaitu :

a. Ketidak mampuan dibidang ekonomi. Termasuk dalam kelompok ini adalah fakir, miskin, gharim dan ibn sabil. Harta zakat diberika kepada mereka selain riqab untuk mengatasi kesulitan ekonomi yang menimpa mereka (Enizar, $2004:$ 19). 


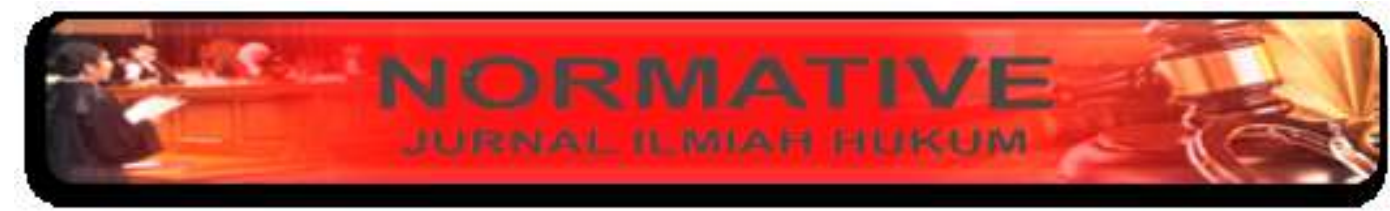

Jurnal Normative Volume 5 Nomor 2 Tahun 2017 ISSN : 1907-5820

b. Ketidak berdayaan dalam wujud ketida bebasan dan keterbelengguan untuk mendapat hak asasi sebagai manusia, maka riqab diberikan untuk membeli kemerdekaannya. Ini berarti zakat diberikan untuk mengatasi ketidak bebasan dan keterbelengguan mendapatkan haknya sebagai manusia. Karena dalam sejarahnya, budak diperlakukan tidak manusiawi dapat digauli tanpa nikah dan dapat diperjualbelikan,

2. Kemaslahatan umum umat Islam

Pada bagian kedua inimendapatkan dana zakat bukan karena ketidakmampuan financial, tapi karena jasa dan tujuannya untuk kepentingan umum umat Islam, yang masuk ke dalam kategori ini adalah amil, muallaf dan fisabilillah.

Keterangan yang dapat menerima zakat oleh imam mazhab (Abdul Aziz Dahlan, 1997: 1996) yaitu :

1. Fakir

Fakir adalah mereka yang tidak mempunyai harta atau penghasilan yang layak untuk memenuhi keperluannya; sandang, pangan, tempat tinggal dan keperluan pokok lainnya, baik untuk diri sendiri maupun bagi mereka yang menjadi tanggungannya. Pengertian fakir ini telah disepakati oleh ulama Syafi' I, Maliki dan Hambali.

2. Miskin

Miskin adalah bentuk jamak dari kata al-masakin. Kelompok ini merupakan kelompok kedua penerima zakat. Orang miskin adalah orang yang memiliki pekerjaan, tetapi penghasilannya tidak dapat dipakai untuk memenuhi hajat hidupnya. Seperti orang yang memerlukan sepeuluh, tetapi ia hanya mendapatkan delapan, sehingga masih belum dianggap baik dari segi makanan, pakaian dan tempat tinggalnya.

Kepada penerima zakat yang miskin ini, organisasi amil zakat perlu memberikan bagian zakatnya dalam bentuk modal pengembangan usaha atau peralatan yang diperlukan. Selain itu mereka juga diberikan bimbingan pengembangan usahanya dan pembinaan-pembinaan seperlunya, agar usaha mereka dapat maju berkembang dan dapat mensejahterakan keluarganya. Merekapun diupayakan agar nanti pengahsilannya selalu meningkat dan pada akhirnya mereka mampu menjadi pembayar zakat yang baik. 


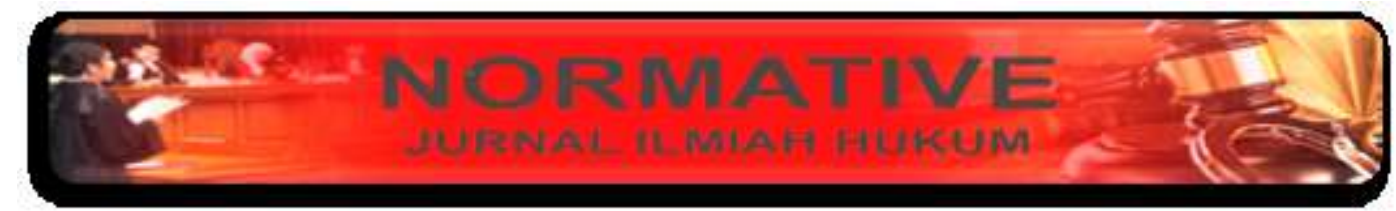

Jurnal Normative Volume 5 Nomor 2 Tahun 2017 ISSN : 1907-5820

3. Amil zakat

Amil zakat (dalam istilah al-Qur'an disebut dengan al-'amilin 'alaiha) adalah orang yang bertanggungjawab melaksanakan segala sesuatu yang berkenaan dengan zakat, mulai dari mendata wajib zakat, mengumpulkan, memelihara dan mendistribusikan kepada orang yang berhak menerimanya. Oleh sebab itu Islam tidak ketinggalan dalam memperhatikan hak para amil dikarekan pekerjaan mereka yang harus teliti dan ulet, di samping itu kadar amal amil zakat yang menentukan kesejahteraan para penerima zakat lainnya.

4. Muallaf

Ada beberapa macam muallaf yang dikemukakan ulama fiqh, di antaranya adalah :

a. Muallaf muslim ialah orang yang sudah masuk Islam tapi niatnya atau imannya masih lemah, maka diperkuat dengan diberi zakat.

b. Orang yang telah masuk Islam dan niatnya cukup kuat dan ia terkemuka dikalangan kaumnya. Ia diberi zakat dengan harapan kawan-kawannya akan tertarik masuk Islam.

c. Muallaf yang dapat membendung kejahatan orang kafir yang di sampingnya.

d. Muallaf yang dapat membendung kejahatan orang yang membangkang membyar zakat.

5. Ar-Riqab (untuk memerdekakan budak)

Yang dimaksud dengan raqaba atau riqab adalah kelompok budak. Kelompok budak merupakan orang-orang yang kehidupannya dikuasai secarab penuh oleh majikannya. Kelompok inu berhak mendapatkan dana zakat dengan tujuan agar mereka dapat melepaskan diri dari perbudakan yang mereka alami. Dalam rangka membebaskan budak, ada beberapa cara yang dapat dilakukan, yaitu :

a. Membantu budak mukattab yaitu budak yang telah bersepakat dengan tuannya bila ia dapat menghasilkan harta tertentu maka ia akan bebas.

b. Membeli budak untuk kemudian dirinya dimerdekakan

c. Melakukan kegiatan pendampingan agar mereka menjadi budak dapat dibebaskan. 


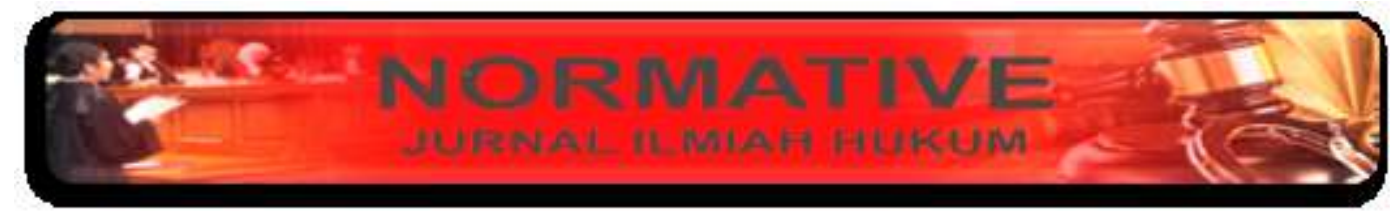

Jurnal Normative Volume 5 Nomor 2 Tahun 2017 ISSN : 1907-5820

Mengingat golongan ini sekarang tidak ada lagi, maka kuota zakat mereka dialihkan ke golongan mustahik lain menurut pendapat mayoritas ulama fiqh. Namun sebagian ulama berpendapat bahwa golongan ini masih ada yaitu para tentara muslim yang menjadi tawanan.

6. Orang yang berhutang (al-Garimin)

Mereka adalah orang yang memiliki hutang, baik hutang itu untuk dirinya sendiri atau bukan, baik hutang itu dipergunakan untuk hal-hal yang baik maupun untuk melakukan kemaksiatan. Apabila hutang itu untuk keperluannya sendiri, dia tidak berhak mendapatkan bagian dari zakat kecuali ia dianggap fakir dan jika hutang itu untuk keperluan orang banyak yang di bawah tanggungjawabnya, untuk menebus dosa pembunuhan atau menghilangkan barang orang lain, dia boleh diberi bagian zakat meskipun dia sebenarnya kaya.

7. Sabilillah

Jumhur ulama fiqh mengartikannya sebagai sukarelawan perang untuk menegakkan agama Allah SWT dan pemerintah, sedangkan mereka tidak menapatkan gaji dari pemerintah. Ibnu Asir seorang ahli hadis dan fiqh mengatakan bahwa salah satu arti sabilillah adalah setiap amalan atau perbuatan ikhlas yang digunakan untuk mendekatkan diri kepada Allah, baik bersifat pribadi maupun kemasyarakatan, termsuk jihad dan perang dalam arti luas.

8. Ibnu Sabil

Ibnu sabil adalah orang yang melakukan perjalanan bukan untuk maksiat dan dalam perjalan ini mereka kehabisan bekal. Menurut Yusuf al-Qardawi Ibnu Sabil dalam kaitannya dengan zakat adalah seluruh bentuk perjalanan yang dilakukan untuk kemaslahatan umum yang manfaatnya kembali kepada agama Islam.

\section{Tinjauan Hukum Islam terhadap Zakat Fitrah dalam Bentuk Uang}

Ibnu Mundzir dalam ensiklopedia Ijma' mengatakan para ulama konsensus bahwa zakat fitrah sah dengan membayar gandum atau kurma seberat $1 \mathrm{sha}$ ' $(2,5 \mathrm{~kg})$. Dalam hadist riwayat Ibnu Umar r.a. Rasulullah s.a.w. memerintahkan zakat fitrah sebanyak 1 shah' kurma atau gandum kepada orang merdeka, hamba sahaya, laki-laki, 


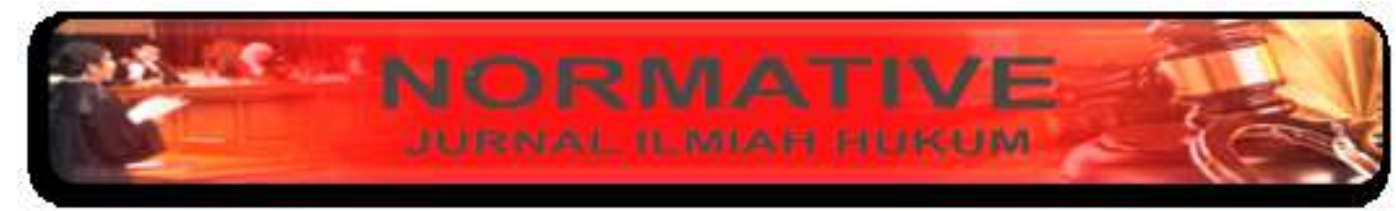

Jurnal Normative Volume 5 Nomor 2 Tahun 2017 ISSN : 1907-5820

perempuan, orang tua dan anak-anak dari kaum muslimin dan beliau memerintahkan agar zakat tersebut dibayarkan sebelum kaum muslimin menjalankan sholat ied. (H.R. Bukhari).

Hadist tersebut diriwayatkan dalam versi lain dengan tambahan "Cukupilah kebutuhan mereka sehingga mereka tidak meminta-minta di hari idul fitri’. Tambahan ini diriwayatkan oleh Dar Quthni, Baihaqi, Hakim dan Ibnu Addi. Menurut Ibnu Hajar semua riwayat tersebut lemah. Dari beberapa hadist tentang zakat fitrah yang ada, para ulama sepakat mengatakan sah hukumnya mengeluarkan zakat fitrah dalam bentuk bahan makanan pokok seperti gandum atau beras atau bahan makanan lainnya.

Mengeluarkan zakat Fitrah dalam bentuk uang senilai satu sha' bahan makanan :

1. Terjadi perbedaan pendapat di sini. Imam Malik, Syafi'i dan Ahmad mengatakan zakat fitrah hanya boleh dibayar dalam bentuk bahan makanan pokok masyarakat setempat. Mengeluarkan zakat fitrah dalam bentuk mata uang tidak sah, kecuali dengan mekanisme mewakilkan untuk membeli bahan makanan. Jadi pada saat memberikan uang kepada amil, tujuannya adalah mewakilkam kepada amil untuk membeli bahan makanan lalu disalurkan kepada mustahiq. Alasan pendapat ini adalah hadist di atas yang menyebutkan bahwa Rasulullah s.a.w. memerintahkan mengeluarkan zakat dalam bentuk bahan makanan.

2. Imam Hanafi berpendapat mengeluarkan zakat fitrah dalam bentuk uang senilai bahan makanan hukumnya sah. Abu Ja'far, salah seorang ulama Hanafi bahkan mengatakan membayar zakat fitrah dalam bentuk mata uang lebih utama dari pada dalam bentuk bahan makanan, alasannya karena itu lebih dibutuhkan kaum fakir miskin dalam banyak kasus. Pendapat kedua ini menggunakan dalil riwayat tambahan di atas bahwa tujuan zakat fitrah adalah agar kaum fakir miskin tidak meminta-minta di hari idul fitri, itu dapat diwujudkan dengan membayar zakat dalam bentuk uang juga. Sebagian ulama mengatakan dalam kondisi sangat dibutuhkan atau darurat, mengeluarkan zakat fitrah dalam bentuk uang diperbolehkan. Para ulama yang mendukung pendapat imam Hanafi ini adalah Umar bin Abdul Aziz, Tsauri, Hasan Basri. Ibnu Taimiah dan Ibnu Qayyim dari ulama Hanbali juga mendukung pendapat ini.

Berdasarkan keterangan-keterangan diatas, maka zakat fitrah menggunakan uang sebagai gantinya adalah sah dan tidak menyalahi syariat islam. Yang harus 


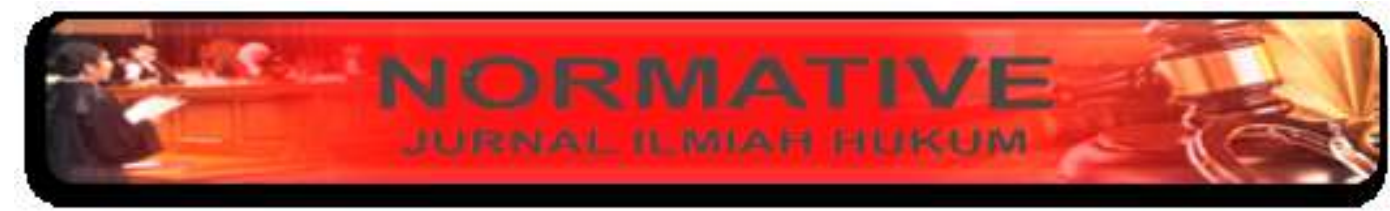

Jurnal Normative Volume 5 Nomor 2 Tahun 2017 ISSN : 1907-5820

diperhatikan yaitu jumlah uang harus setara dengan beras (dalam zakat fitrah) tersebut jika diuangkan.

\section{E. Kesimpulan}

Zakat fitrah adalah ritual maliyah yang dilaksanakan setiap tahun. Pembayaran zakat fitrah pada umumnya menggunakan beras sebagai bahan makanan pokok yang lazim dikonsumsi masyarakat. Namun ada pula yang membayarkan atau menyelenggarakan pengelolaan zakat fitrah dengan uang. Jika menggunakan beras, zakat fitrah yang dibayarkan sejumlah $2,5 \mathrm{~kg}$ beras. Jika menggunakan uang, zakat fitrah yang dibayarkan menyesuaikan dengan harga beras yang berlaku di pasaran. Oleh karena itu orang lebih mudah mendapatkan uang dari pada bahan makanan pokok. Dengan demikian, memberikan zakat dalam bentuk uang terbukti telah memberikan maslahat bagi umat dan ini dibolehkan dalam hukum Islam. 


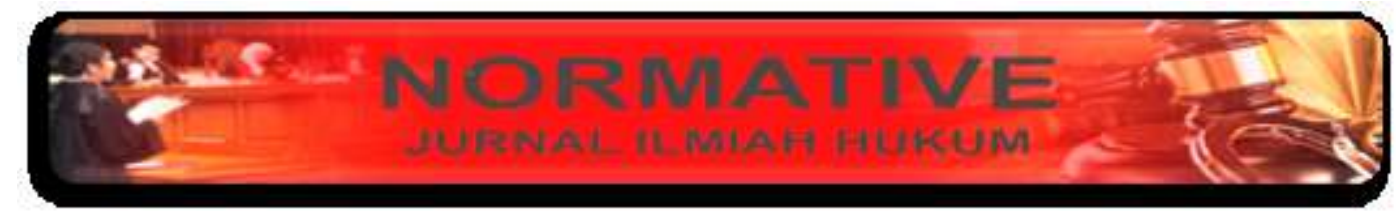

Jurnal Normative Volume 5 Nomor 2 Tahun 2017 ISSN : 1907-5820

\section{DAFTAR PUSTAKA}

Al Fauzan, Saleh. Fiqih Sehari-hari, Jakarta: Gema Insani, 2006 Al Maqdisi,

Ali, Muhammad Daud. Sistem Ekonomi Islam, Zakat dan Wakaf, Jakarta: UI Press, 1988

Ash Shiddieqy, Muhammad Hasbi. Pedoman Zakat, Semarang: Pustaka Rizki Putra, 1999

Hasan, Sofyan. Pengantar Hukum Zakat dan Wakaf, Surabaya: Al-ihlas, 1995

Nawawi, Ismail. Zakat dalam Prespektif Fiqh, Sosial dan Ekonomi, Surabaya: CV. Putra Media Nusantara, 2010

Nurdin, Muhammda Ali. Zakat sebagai Instrumen dalam Kebijakan Fiskal, Jakarta: Raja Grafindo Persada, 2006

Qardawi, Yusuf, Fiqh Zakat, Terj. Salman Harun, et.al., Jakarta: Litera Antar Nusa, Cet. 6, 2002

Zuhaili, Wahbah. al-Fiqih al-Islam wa Adilatuhu, Terj. Agis Effendi, et.al., Zakat Kajian Barbagai Madzhab. Bandung : Rosdakarya, 1995

Zuhri, Saifuddin. Zakat Kontekstual, Semarang: CV. Bima Sejati, 2000Sayyid Sabiq, Fiqh asSunah, juz 11l, Kuwait : Dar al-Bayan

https://www.merdeka.com/ramadan/hukum-membayar-zakat-fitrah-dengan-uang.html 